\title{
Space and Approach in "The Virtuous City": A Tale of Two Universities: Re-imagining and reconstruction of the westernised South African university
}

\section{Dr. Quraysha Ismail Sooliman}

Faculty of Humanities/Mellon Foundation, University of Pretoria, South Africa and

\section{Iram Yousuf}

Faculty of Humanities/Mellon Foundation, University of Pretoria, South Africa

\section{DOI - https://doi.org/10.35293/srsa.v43i1.338}

\section{Abstract}

In order to know how to change one must be able to acknowledge what one does not know. Central to knowledge production of relevance is humility and an understanding of the realities of one's own environment. From a decolonial perspective, knowledge production is affected by the development and creation of the actual physical spaces of the university and its pedagogy. The Covid_19 pandemic has tested the functionality of the physical space of the university as well as the organization of the city space. This paper considers these issues, their impact and effect on the mental well-being of both academics and students by exploring the idea of the university as a virtuous city. We draw on Al-Farabi's treatise of the Virtuous City because physical and conceptual architectures reflect a way in which the world is structured. In South Africa, the violent design of the fragmented spaces has been planned according to the colonial, cartographic imagination which destroys and distorts memory and ruptures tradition. The architecture of the cities and universities, it can be argued, effect a similar process, and serve as an affirmation of the pre-dominance of the white-supremacist power structure in South Africa. Cities are created by people and each city is a creation of the interaction of social, economic, cultural, and political imperatives. The university is a micro-manifestation of the cosmopolitan city that adopts different approaches to knowledge, decolonisation and transformation. In re-imaging and reconstituting the westernised South African university an appropriate approach to reaching the ideals of well-being and harmony would require the shedding of 
the ego and the Cartesian "I". The process of decolonising the university should occur by deconstructing and recognising colonial methods, theories and practise in our pedagogy and spaces in order to begin the process of reconstruction.

Keywords: Decoloniality, intellectualism, neo-liberalism, humility, academic activism, pedagogy, politics, mental illness, fear and well-being

"A multitude of people and yet a solitude."

- Charles Dickens, A Tale of Two Cities

\section{Introduction}

Critically engaging the traditions, ethics and architecture of other cultures is an invigorating experience. It is about immersing oneself into the diversity of knowledge and creative expression that exists. The westernized university has been designed to typically reflect the European city. Structures of power, such as the city/university, have been consolidated with knowledge and images that distort the identity of the colonised. Land use has become a rationalised terrain measured by racialisation which perpetuates both alienation and the operation of privilege. Formerly colonised people struggle within these spaces. It is in these spaces that specific experiences are noted. Memories are trapped, dignity is enfringed upon and human rights has little currency. This chapter explores how, in building the world of you- the world of the white western male, and allowing it to dominate institutions of knowledge, the sense of Othering, and/ or inferiority that is experienced by the citizens (students) leads to an increase in mental illness. Othering contributes to a sense of inferiority, as the pedagogical approach and content is alienating and oftentimes irrelevant to the context, culture and consciousness of South African students. According to Ramose ${ }^{1}$, rather than an African University in South Africa, what we had and continue to have are Universities in Africa. For coherence, the chapter is interwoven with discussions on the university space as developed through a colonial vision and is then contrasted with the virtuous city. This is because the way in which both physical and conceptual architectures come to be, reflect a particular way in which the world is structured. This must be (un)imagined and re-imagined. 1 In Dr. T Lebakeng and Prof MB Ramose, The Right to be an African University (unpublished) 
Included in this tapestry of creative reimaging is a discussion on the approach to pedagogy by focusing the lens on aspects of knowledge production and the ethics of the academic.

Transformation and decolonisation are not synonymous, they refer to two different aspects of what must happen to the university in a post-colonial age. Additionally, "decolonization is not a metaphor... Decolonization is accountable to Indigenous sovereignty and futurity” (Tuck and Yang 2012:1\&35). It opposes the neoliberal conceptualisation of knowledge and knowledge systems that commodify knowledge. To know this is to realise that knowing is not enough. Rather, to know, requires that we act from this knowing. It is a responsibility to re-imagine from this moment. It is to re-establish the ethical. We say ethical because the effects of a Eurocentric approach have harmful consequences for South Africans as it produces graduates with little knowledge, understanding or sympathy for the reality of their country. It is harmful because it fundamentally undermines the responsibility of the university to contribute to the social good.

The social good is fundamental to a national vision in a society as fractured as South Africa. Here education has always been political. The responsibility and ethical commitment should thus be on developing the individual to respond to these challenges rather than constituting the university as an institution for training students to become ready for the job-market. The job-market as we know it in South Africa is also racialised and supports the perpetuation of racial capitalism. If the university continues to feed into this system without offering alternatives, critique or creative solutions then it is not fulfilling its role as a contributor to the social good. Education is a vital resource to the democratic and civic life of a nation and teaches us that it is not only the individual but the social that can transform this country and its understanding of humanity. Thus, there needs to be a 'buy in' into this vision by all stakeholders. It is here that we acknowledge the activism in the \#FeesMustFall (\#FMF) and \#RhodesMustFall protests. These protests challenged the South African academia to reconsider power, power structures and knowledge production in the academia. The protests ignited a critical reflection and imagining around questions of decolonisation versus transformation. What has become apparent subsequently, is that there is resistance from sectors of the academia, from politicians and some elites to decolonisation. In other words, we are still struggling with the rules of engagement despite knowing that critical pedagogy must be contextualized in its cultural 
and political content. These dynamics are linked to the role of educators who need to rethink the inter-connectedness between politics, culture, education and power. Healthy, functional and relevant social, conceptual and lived architectural spaces are necessary for providing young people with the intellectual, material and psychological resources they need to participate in and shape the diverse economic, political, and social conditions influencing their lives. The university space should also be such a holistic space, a city of positivity and nurturing.

\section{On the City}

\subsection{Colonialism, Cities, and the University}

The words colonialism and colonisation derive from the Latin word colere, which means to design or cultivate. Whilst the historical colonial experience of the colonised reflects the opposite of the 'feel good meanings' in these words, the tenacity of the colonisers to organise and transform non-European areas into what are fundamentally European constructs cannot be underestimated. This propensity to build in the European image has also infiltrated knowledge production so that one cannot view the effect, impact and construction of the city without considering its machinations and systems of operation in order to re-imagine these spaces for the decolonisation process. Consequently the "world of you" (Fanon 1963, 188) that is built, is the one that is dominated by the white western male. The westernised university is no exception to this. From its aesthetic to the way it operates, the university has been designed to typically reflect European city- gardens, housing quarters, names, culture, religious identity and art. These are aesthetically apparent and they permit the continued existence of a racialised hierarchy to exist, through unchanging structural practices and Othering via the spaces. Populated with specific names, statutes and architectural styles they remind not of philanthropy or benevolence but of the destruction and devastation from looted landscapes which have destroyed societies, severed knowledge systems and fragmented identities.

As a result, the essence and material effect of the structure affects the community that is established within the university. It is here that memories and experiences become trapped and for South African students despite 
entering with the hope of breaking the shackles of oppression, they continue to experience the effects of coloniality. The colonised mind seeking liberation drifts helplessly in the colonised space where learning should be an intellectual engagement not just job-readiness preparation. Without power and hegemony, its possibilities are limited. During the Covid_19 pandemic these inequalities have been exacerbated as access to online learning and resources for students from different universities have highlighted the fragmentation and racialisation of higher education. Additionally, obstacles to emancipatory pedagogies have surfaced. For the majority black students, it is a violent encounter yet again. They have to function in spaces inherently unconducive to learning and development due to the apartheid cartography.

\subsection{The Colonial City, the Virtuous City and the UniverCity}

Colonialism and capitalism, which shaped much of the globalised twentyfirst century has given birth to (often) violent, unequal, and polluted cities in the world. These diverse cities often swirl with chaos. Part of this chaos can be attributed to the designers, planners, and architects who, perhaps intentionally, never considered the mental well-being of urban citizens, nor have they sought to challenge the aspects of inequality that manifest as a result of these spaces. Such occurrences reflect the attitude or even (un)ethics of the architect. Consider Le Corbusier's letter to Il Duce's French ambassador (Poplack 2018,1), which is a promise that is a 'denial of coevalness' (Fabian 1983, 31). Coevalness can be defined as a sharing of present time. Its denial manifests when colonialists consider Africa to be "backwards." Time cannot be shared presently if one party to the time is lagging. In his letter, Le Corbusier (in Poplack 2018) states that the city models he designed for Addis Abba would be so "severe, that one might think the colony was a space without time, and therefore, without history, and without any particular geographical meaning." By implication, Le Corbusier alluded to the idea that Africa's overcrowded, ungovernable cities must be remapped if the continent and its people are to have any future (Poplack 2018, 1). According to our interpretation, this idea of "remapping" African cities and by implication, knowledge production had to be co-opted and manipulated, in order to make the populace subservient; because subservience will afford them a "future." Furthermore, "the city is direct dominion; the city becomes the city of 
government," recognising that the architecture of a city establishes an identity, and this in turn sets forth the hierarchies of power. Once (the idea of) power is established, it dominates over all those within its space, and bends them according to its will. As a result, the colonised experience a sense of Othering, and/or inferiority (Fanon 1963, 188). In this world, that is the world of the European white male, they are objects, and can only see themselves through a Eurocentric image (Quijano 2004, 204).

Prior to colonialism, many cities were organised and structured in a different manner and layout to present day cities. For millennia there have been thriving urban societies such as those found in Damascus, which, was established in the third millennium $\mathrm{BC}$ and is one of the few cities in the world that has been continuously inhabited (Battuta and Lee 2013, 83). These societies have been cultivated by diverse philosophers and intellectuals who have tried to make the urban space an articulation of the aspirations of each culture and societyincluding aspects of moral, spiritual, and material well-being. According to urban theorist Louis Mumford's conception, cities were originally vessels for the sacred - places where the gods lived, and so too the communities that worshipped them (Poplack 2018,1). Thus, when developing a city, one is faced with the seemingly complex task of cultivating and creating spaces that do, and will, nurture both material and mental well-being. Nurturing is possible through ethical conduct infused with humility. This has been evident in the tradition and behaviour of the renowned and recognised Muslim scholar Imam Malik. Imam Malik bin Anas (b. $93 \mathrm{AH}$, d. $179 \mathrm{AH}$ ) was one of the greatest Islamic scholars of all times. His more than 1300 disciples from all walks of life included rulers, judges, historians, Sufis, poets and students of Islamic texts. The Caliph of the time attended his classes as an ordinary student. Imam Malik showed great respect for knowledge. He considered his own knowledge as a trust and confidently stated that half of knowing is the ability to say 'I don't know'

This reflects an awareness of the importance and value of knowledge, of the responsibility the carrier of knowledge has and of the humility that knowledge should foster. Not arrogance. Not self-entitlement and not self- glorification. It allows for an approachable repertoire to be built between the 'still learning student' and the esteemed professor who is meant to endear the student to their subject. Sharing knowledge and elaborating on instances of co-operation affirms the inter-connectedness between different people whilst eroding the self-conceit 
inherent in western civilisation of superiority in their knowledge canon. Examples such as Napoleon's appreciation of Imam Malik's knowledge and treatises should not be hidden but discussed so that students can learn to appreciate excellence wherever they find it. According to David Moussa Pidcock (taken from Kamali 2019, 272) in his book Napoleon and Islam "96 percent of the Napoleonic code came from the rulings of Imam Mâlik.” The Napoleonic code is the French civil code and is recognised for shifting the focus from feudal laws to laws that are more accessible and clearly written. This sharing of all knowledges is essential for an 'education city' where vast numbers of people gather daily in order to learn, reflect, engage, create and produce beneficial outcomes that contribute to human development. It is a space directed at the social good. Consequently, for cities to represent their citizens, they should hold cultural and spiritual appeal.

Al-Farabi deemed this well-being and care for occupants and is one of the pillars in obtaining a virtuous city (Al-Farabi 1985, 433). This virtuous society formed part of the greater notion of the philosophy of society (falsafiya madaniyya). Al-Farabi's philosophy of society relies on society working together to create the virtuous city. Accordingly, " $[\mathrm{t}]$ he virtuous city [then] resembles the perfect and healthy body, all of whose limbs cooperate to make the life of the animal perfect and to preserve it in this state." (Al-Farabi, 1985, 231). This requires a leader who possess the necessary wisdom and knowledge to care for the city. It is through this wisdom and knowledge, and the leader's engagement with society that this leader (or Vice Chancellor) then becomes capable of seeing problems that are yet to befall the city. The leader plans ahead to solve particular predicaments which exist at present, unlike those who had detached themselves from society, and through their faulty judgments bring ignorance and wickedness to their cities (Al-Farabi, 1985, 245-253). If one compares this approach to that of the entrepreneurial structure of the neo-liberal university of today, the consequences are self-evident. Where profit is prioritised over people, the social good, sustainability, cosmic harmony and nation building are sacrificed. In the South African context, the violent responses from the universities and securitisation of university spaces during the \#MustFall protests are a testament to this issue. For Al-Farabi $(1985,229)$ the essential elements of the city are multiple. These include to create a place which ensures social security for its inhabitants; a place where the virtuous live; a place that is governed by wise individuals; a place which contributes to spirituality and religion; a place that ensures urban harmony of 
all environmental, social, and cultural conditions; a place with an emphasis on public spaces and services; a place where all citizens are recognised as human and thus have, and observe, equal human rights. Al-Farabi is supported by Ibn Khaldun who considers cities being built as a necessary development for people's civilisational growth because it is in these spaces that they come together and exchange knowledge, seek tranquillity, restfulness, and relaxation (Ibn Khaldun 1967, 235-238).

Furthermore, cities are created by people and each city is a creation of the interaction of social, economic, cultural, and political imperatives at each moment of the city's development (Lea \& Courtney 1985, 1). In this context, the role of planners and architects is profoundly linked to the historical and cultural context of the cities in which they live. For Al-Farabi $(1985,230)$ the path to attaining the perfect society can be achieved through education, and the drive by man to obtain perfection. The entire activity of education is about the acquisition of values, knowledge and practical skills by the individual, within a particular period and a particular culture. Education must, at its core, lead the individual to perfection since the human being was created for this purpose. The perfect human being (al-insan al-kamil), is one who has obtained theoretical virtue-thus completing their intellectual knowledge, and having acquired practical moral virtues, becoming perfect in their moral behaviour. Crowning these theoretical and moral virtues with effective power, are the individual members of the community who assume the responsibility of political leadership, thus becoming role models for other people. Here Al-Farabi unites moral and aesthetic values: good is beautiful, and beauty is good; the beautiful is that which is valued by the intelligentsia (Al-Farabi 1985, 230). This perfection which he expects from education combines knowledge and virtuous behaviour; it is happiness and goodness at one and the same time. The emphasis is thus, that architecture and space influences life, and when coupled with leadership, they determine the way in which a community develops.

Freire $(1972,71)$ echoes these sentiments, arguing that the purpose of education is to enable people to become fully human, so that they can act to change their world together with others. Decolonising a space is to ethically examine the types of practises and programmes, be they academic, structural, cultural and/or social that have resulted in South Africans calling for alternate approaches and 'persons' (read: voices/knowledge) to be brought into representative university spaces. It 
is asking about why this/they have been excluded in the first place and for what benefit? It requires that we reimagine how and what we teach so that we do not re-inscribe the colonial archive, acting as if the colonial library is the only library. The reconstruction process a free imagination unshackled from the mind that has been disciplined by the colonial project. Additionally, decolonisation of the curriculum "is neither an advocacy to be anti-West, nor is it discouragement to learn from the West and the rest of the world. It is a call to make higher education relevant to the material, historical and social realities of the communities in which universities operate" (Letsekha 2013:14). Considering that there are many ways of being and learning it is plausible to state that the potential exists for a 're-imagining' that can change the way in which we deal with the issue of the human by engaging with other traditions, non-western thoughts and ethics. This is because "mainstream educational discourse not only ignores the ideological nature of teaching and learning, it also erases culture from the political realm by enshrining it either as a purely aesthetic discourse or as a quasi-religious call to celebrate the 'great books' and 'great traditions' of what is termed 'Western Civilization"” (Giroux 2000, 13).

Additionally, custodians of knowledge have an ethical duty to use knowledge constructively and "ethically university-based academic leaders must become public intellectuals who engage the larger public through writing, speaking, or acting" (Parsons 2013, 2). An academic cannot withdraw into the ivory tower and estrange their work and its relevance from the society in which they exist. The ethical duty is understood from the "Greek ethical ideal of adding 'character' to a society" (Parsons 2013, 4). This consolidates the above argument about the virtuous city, its architectural landscape and the production of knowledge which should combine to eliminate inequality, superiority-inferiority hierarchies and arrogance. It is in this creative re-imagining of the education city that one recognises the threat to well-being posed by the rise of corporate culture's power to eradicate the importance of pedagogy as an ethical and political act. What we have is the packaging of pedagogy as a technical and instrumental practice that promotes higher education primarily as a financial investment. British cultural theorist Richard Johnson points out:

Teaching and learning are profoundly political practices. They are political at every moment of the circuit: in the conditions of production (who produces 
knowledge? for whom?), in the knowledges and knowledge forms themselves (knowledge according to what agenda? useful for what?), their publication, circulation, and accessibility, their professional and popular uses, and their impacts on daily life. (Richard Johnson 1997:461)

In the current global context, the ideas developed should confront neoliberal thought and implementation because "the power of neoliberalism lies in its saturation of social practices and consciousness, making it difficult to think otherwise" (Lipman 2011,6). The deregulation inherent in neoliberalism facilitates for private and privileged interests and serves white supremacist goals, especially where those goals and ambitions are entwined with market forces. As a result, there is a reluctance to enable critique and motivation for discussions on the language of social investment, protection, justice, equality and accountability, all of which are exacerbated by short-term contracts, downsizing and "competition between individuals through strategies of individualisation and responsibilisation” (Hofmeyer 2008, 75). Knowledge and learning have become subject to the politics of disposability, what Said $(1994,12)$ refers to as the twin dynamics of "accommodation and privatisation", reflecting the culture of professionalism in the different educational levels. According to Said $(1994,13)$ professionalism is where one thinks of one's "work as an intellectual as something you do for a living, between the hours of nine and five with one eye on the clock, and another cocked at what is considered to be proper, professional behaviournot rocking the boat, not straying outside the accepted paradigms or limits, making yourself marketable and above all presentable, hence uncontroversial and unpolitical and 'objective" This gives rise to a group(s) of citizens who exist in the zone of non-being. In the language of neoliberalism, words and concepts that were used to describe the market and market related issues are now applied to the human so that the human factor is reduced to economic descriptors where value is based on material profit, not ethics, not excellence in character and contribution and certainly not in terms of well-being.

\subsection{Mental Illness and the UniverCity}

However, the university, resembling a city, should be designed and cultivated according the political, social, historical, and cultural regions in which they 
are situated. Through its structuring, students then act as citizens within this city, and their interactions are such of those between citizen and state. But, the notion of the university as a public good has been abandoned in this conversion of the university to a micro-state. Instead the university now sees itself as "a quasi-sovereign entity that no longer recognises the fact that it owes the public anything" (Praeg, 2018, 9). From the oral traditions, Imam al- Raghib al-Asfahani a teacher of Islamic philosophy, states that where there is love there is no need for law. If the city loves its citizens, it needs to see to their needs, and it needs to do so with foresight. This is the nature of a virtuous city. When citizens have to demand their rights, it means that the citizens are aware of their rights, and when you are aware of your rights, it is a sign of the absence of law, and a city without virtue. The awareness of one's own rights indicates that the rights are infringed upon. The city in this sense, is wicked and cruel, and this becomes apparent in the way in which it deals with its citizens. Students (citizens) are often marginalised and discriminated against by the law and by power structures should they dare to "rock the boat." While they may have rights, accessing those rights may be difficult (Gordon 2007).

The zone of non-being produces and maintains unbearable conditions of existence that often result in mental, psychological, social and spiritual death (Yousuf 2019,3). This resonates with Mphahlele's "tyranny of place" which refers to context and its impact on content, to how 'place' assigns identity and of being severed from one's roots (Obee 1994,13). What we have then is about educating for accommodation and not the ideal of linking learning to social change. This leads to students, who are the citizens of the state feeling breathless (MaldonadoTorres 2016,5). Breathlessness, however is not limited to students, but increasingly black academics find themselves suffocating. Under constant surveillance by the university to stay away from anything "too radical," burdened by journals which require a stricter standard of substantiation if the writing is not centred in the western canon, confined to a space that still reeks with coloniality, and constantly reminded of their place by the symbols of white power and control, academics and students begin to feel as if the constant condition in the city is a state of subordination, alienation, coloniality and disregard, which increases in certain contexts. If academics or students stray too far from what the university has deemed acceptable, the university then exercises a veto power over their livelihood and life (see Yousuf 2019). This goes against Ibn Khaldun's idea that a 
city (the university) should promote tranquillity, and relaxation, and should be a place where knowledge is exchanged, as opposed to commodified and traded.

Furthermore, by limiting knowledge and universalising the experience of the white western male, the purpose of knowledge- to obtain the perfection of the human, and to allow one to be fully human- cannot be fully achieved. This is because any experience that does not fall into the experience of the white western male is not a recognised experience. It is not surprising then, that several academics and students increasingly become depressed. In 2018, the University of Pretoria experienced at least 23 suicide attempts (Kgosana 2018). Suicides are an expression of extreme mental distress. The World Health Organisation (2014) released a report on suicide in which it states:

Risks linked to the community and relationships include war and disaster, stresses of acculturation (such as among indigenous peoples or displaced persons), discrimination, a sense of isolation, abuse, violence and conflictual relationships ... risk factors at the individual level include previous suicide attempts, mental disorders, harmful use of alcohol, financial loss, chronic pain and a family history of suicide.

Interestingly enough, the report specifically refers to stresses of "acculturation, discrimination and a sense of isolation” (World Health Organization 2014). These are particularly poignant forms of domination that exist within the university. In an opinion piece written by Nyulu and published by the Daily Vox (2019) titled 'Students are not committing suicide, universities are killing us' Nyulu argues that: "institutional racism is... not something that can be seen but rather it's something that one feels. Institutional exclusion is hard to tackle because the university isolates you." Additionally, discriminatory practices which cause one to see themselves through a Eurocentric image place great strain on one's own identity, and contribute to a natal alienation (Yousuf 2019, 1). In order to resist this form of oppression, decoloniality presents as an alternative response. Decoloniality challenges the acceptance of inferiority and the conditions of coloniality. It is coupled with dismantling the superiority ideology of the European, and a radical refutation of the lack of the full humanity of the colonised. According to Maldonado-Torres $(2016,5)$ " $[\mathrm{a}] \mathrm{s}$ a result of this turn, the colonized subject emerges not only as a questioner but also as an embodied 
being who seeks to become an agent". It is however, more than that. It is a holistic movement that involves reaching out to others, communicating, and organizing (Maldonado-Torres 2016, 5)- it is about building a community. It is ultimately about reclaiming spaces and crafting them in a new way. A way that allows for different knowledges and critique to be produced, and for different ways of being, acting, and knowing in the world to come into existence (MaldonadoTorres 2016, 7). What is then built is not the world of you, nor the world of I, but rather it is the world of Us.

Knowledge has limitations and presents conundrums. Astute academics are aware of the pitfalls of knowledge production and dissemination, and especially of their own limitations. That is why they can say: 'I don't know-let's find out together. It is never too late to learn. Scholars who value knowledge recognise this and manifest it in their work. Recognising the limits of one's own knowledge, or the fact that the knowledge one professes to hold dear could be problematic, requires the humility that was so characteristic of Imam Malik, but is largely absent from the westernised university space where academics are chasing rankings, bonuses and claims of 'expertise', so that they can make themselves indispensable. But expertise in what and for whose benefit, and expert according to whom? In instances where academics had engaged in a thoughtful and disciplined social order, increased fragmentation and individualisation in the commodified, westernised, neoliberal university has eroded the potential to critically engage and to be relevant. Academics seek promotion and tenure, and refrain from activism or public dialogue. Instead, the intellectual response has been silence, claiming 'We are transforming. Furthermore, to say 'I don't know' would be to admit to not being the expert, which makes one replaceable. Acknowledging the Other's knowledge and embracing it when in fact it was intentionally ignored, is to admit not knowing. Worse still, it could mean that the Other knows what we do not know and is therefore the real expert, which is scary for many. Thus, for many academics, survival is centred on denial of, and resistance to the decolonial/transformational turn. It can then be argued that, as is the case in politics, academic work rarely pursues the 'good life for all', but rather focuses on material benefit for the 'I' as the market has become the mechanism of social control and identity creation.

The ultimate resource that humans have is their creative potential which needs to be invigorated or nurtured, where people can be inspired to challenge 
stagnant ideologies and ideas to the extent that spaces of academia become spaces wherein the social order is critiqued. For this reason, epistemic decolonisation requires activism, it requires reconstruction and it cannot occur in a political vacuum.

\section{Conclusion}

The university is a micro-manifestation of the cosmopolitan city that adopts different approaches to knowledge, decolonisation and transformation. In re-imagining and reconstituting the westernised South African university an appropriate approach to reaching the ideals of well-being and harmony are needed together with a recognition of the fact that the knowledge that is produced and consumed must be beneficial for that society. Al-Farabi's philosophy of society relies on society working together to create the virtuous city and in extrapolating from this idea to that of the university, it is possible to consider the mental wellbeing of both academics and students by exploring the idea of the university as a virtuous city. If one compares this approach to that of the entrepreneurial structure of the neo-liberal university of today, where profit is prioritised over people, the social good, sustainability, cosmic harmony and nation building are sacrificed, it is evident that in re-imaging the university space one has to move beyond the typical conceptualisation of the European/colonial city. Together with structure, ethos is tantamount. Considering the history of South Africa and the legacy of apartheid it is necessary for academics to re-imagine the role of education, knowledge production and dissemination in the context of decolonisation and transformation. Those in charge of running universities- the city planners, designers, and architects who shape the institution- should give due consideration to the historical and cultural context in which the universities operate, and amend their functioning, institutions, and curricula appropriately so that all the inhabitants are at ease and feel a sense of belonging.

In spaces where the Other feels isolated and alone, the sense of belonging to the city (university) is erased. This has in turn led to an increase in depression and suicide attempts in universities. Safety and ease in spaces of living contribute to greater creativity and output, which requires a shift from the politics of fear and privilege, from the continued embeddedness in a politics of disposability to the re-awakening of political agency and activism in the academia. Decolonisation 
includes a way that allows for different knowledge and critique to be produced, and for different ways of being, acting, and knowing in the world to come into existence. What is then built is not the world of you, nor the world of I, but rather it is the world of Us.

\section{References}

Al-Farabi, A.N.M \& Walzer, R. 1985. Al-Farabi on the Perfect State: Abū Nasr AlFärābì's Mabādi-Ārä-Abl Al-Madina Al-Fädila: A Revised Text with Introduction, Translation, and Commentary. London. Oxford University Press.

Battuta, I \& Lee, S. 2013. The travels of Ibn Battuta: in the near east, Asia and Africa, 1325-1354. Mineola. Dover Publications.

Fabian, J. 1983. Time and The Other How Anthropology Makes Its Object. New York. Columbia University Press.

Fanon, F. 1963. Black Skin, White Masks. Harmondsworth. Penguin.

Freire, P. 1972. Pedagogy of the Oppressed. New York. NY: Continuum.

Giroux, H. A. 2000. "Public Pedagogy and the Responsibility of Intellectuals: Youth, Littleton, and the Loss of Innocence" JAC 20(1)

Gordon, L. R. 2007. "Through the hellish zone of nonbeing: Thinking through Fanon, disaster, and the damned of the earth" Human Architecture: Journal of the Sociology of Self-Knowledge 5(3): 5-11.

Grosfoguel, R. 2009. "A Decolonial Approach to Political-Economy:

Transmodernity, Border Thinking and Global Coloniality” Internet: http:// www.postkolonial.dk/artikler/kult_6/GROSFOGUEL.pdf. Access: 13 June 2019.

Hofmeyer, B. 2008. "Beyond the Ivory Tower: The Public Role of the Intellectual Today" Phronimon, 9 (2)

Johnson, R. 1997. "Reinventing Cultural Studies: Remembering for the Best

Version” From Sociology to Cultural Studies: New Perspectives. Edited by Elizabeth Long. Malden, MA: Blackwell

Kamali, M. H. 2019. Crime and Punishment in Islamic Law: A Fresh Interpretation.

Oxford Univesity Press. New York: NY

Kgosana, R. 2018. "UP students' march shines light on depression, suicides"

Internet: https://citizen.co.za/news/south-africa/2024995/pics-up-studentsmarch-shines-light-on-depression-suicides/. Access: 14 June 2019 
Lea, J. \& Courtney, R. 1985. "Cities in conflict: studies in the planning and management of Asian cities" Internet: http://www-wds.worldbank.org/ external/default/WDSContentServer/WDSP/IB/1999/11/10/000178830_9810 1911003171/Rendered/PDF/multi_page.pdf. Access: 13 June 2019.

Letsekha, L. 2013. "Revisiting the debate on the Africanisation of higher education: An appeal for a conceptual shift” The Independent Journal of Teaching and Learning (8)

Lipman, P. 2011. The new political economy of urban education: Neoliberalism, race and the right to the city Routledge

Maldonado-Torres, N. 2016. "Outline of Ten Theses on Coloniality and Decoloniality” Internet: http://caribbeanstudiesassociation.org/docs/ Maldonado-Torres_Outline_Ten_Theses-10.23.16.pdf. Access: 13 June 2019 Nyulu, S. 2019. “Students Are Not 'Committing Suicide, Universities Are Killing Us” Internet: https://www.thedailyvox.co.za/students-are-not-committingsuicide-universities-are-killing-us-siyamthanda-nyulu/. Access: 13 June 2019

Obee, R. E. 1994. "A Dialogue of two Selves: Themes of Alienation and African Humanism in http://uir.unisa.ac.za/bitstream/handle/10500/15683/ dissertation_obee_re.pdf?sequence $=1$

Parsons, J. 2013. "The Ethical Academic: Academics as Public Intellectuals" Internet: https://files.eric.ed.gov/fulltext/ED539258.pdf Accessed 12 June 2019

Poplack, R. 2018. "Europe's neo-colonial African urbanism” Internet: https:// www.politico.eu/article/europe-neo-colonial-african-urbanism-startup-cities/. Access: 13 June 2019.

Praeg, L. 2018. Postgraduate Address “Just Thinking” - a Decolonial perspective on epistemic justice Postgraduate Conference 01 November 2017, Conference Hall, University of Pretoria

Quijano, A. 2004. Coloniality of Power, Eurocentricism, and Social Classification. Coloniality at Large: Latin America and the Postcolonial Debate. Edited by Mabel, M \& Dussel, D. London. Duke University Press.

Said, E. 1994. Representations of the Intellectual: The 1993 Reith Lectures New York: Pantheon.

Tuck, E. and Yang, K. W. 2012. "Decolonization is not a metaphor". Decolonization:Indigeneity,Education\&Society Vol 1(1) 
World Health Organization 2014. "Preventing suicide: a global imperative" Internet: http://apps.who.int/iris/bitstream/10665/131056/1/9789241564779_ eng.pdf?ua=1. Access 13 May 2019

Yousuf, I. 2019. "Burdened by a Beast: A brief consideration of social death in the South African University" Journal of Decolonising the Disciplines Inaugural Edition. 